УДК 316.776-027.511:165.173

https://doi.org/10.34142/24130060.2020.20.1.02

\title{
ВПЛИВ ІНФОРМАЦІЙНОГО ПРОСТОРУ НА СОЦІАЛЬНЕ ЗДОРОВ’Я СУСПІЛЬСТВА: ГЛОБАЛІЗАЦІЙНИЙ ВИМІР
}

\author{
Н. М. Волвенко \\ Горлівський інститут іноземних мов ДВНЗ «Донбаський державний педагогічний \\ університет» (м. Бахмут)
}

\begin{abstract}
Стаття присвячена проблемі сочіального здоров'я суспільства як найважливішої умови інформаційної безпеки людини. Показано, щзо зі вступом суспільства в інформаційну фазу свого розвитку виникає безліч викликів, загроз і ризиків. Обговорено, щзо інформаційне середовище стає наддержсавним, планетарним, безмежним, щзо виходить за рамки сформованого історично сочіального контролю $i$ сочіального регулювання інформаційних відносин. Виділено параметри соціального здоров'я суспільства, які $\epsilon$ необхідними умовами для забезпечення інформаційної безпеки суспільства.
\end{abstract}

Ключові слова: сочіальне здоров'я, глобалізація інформаційного простору, соиіальний діалог, інформачійна безпека людини.

\section{ВЛИЯНИЕ ИНФОРМАЦИОННОГО ПРОСТРАНСТВА НА СОЦИАЛЬНОЕ ЗДОРОВЬЕ ОБЩЕСТВА: ГЛОБАЛИЗАЦИОННОЕ ИЗМЕРЕНИЕ}

\section{Н. Н. Волвенко}

Статья посвящена проблеме соичильного здоровья общества как важнейтего условия информационной безопасности человека. Показано, что со вступлением общества в информационную фазу своего развития возникает множество вызовов, угроз и рисков. Обговорено, что информационная среда становится надгосударственной, планетарной, безграничной, что выходит за рамки сформированного исторически сочиального контроля и сочиального регулирования информационных отношений. Выделено параметры социального здоровья общества, которые являются необходимыми условиями для обеспечения информационной безопасности общества.

Ключевые слова: сочиальное здоровье, глобализация информачионного пространства, сочиальный диалог, информационная безопасность человека.

\section{THE IMPACT OF THE INFORMATION SPACE ON THE SOCIAL HEALTH OF SOCIETY: A GLOBALIZING DIMENSION}

\section{N. Volvenko}

The article is devoted to the problem of social health of society as the most important condition for information security of a person. It is shown that when a society enters the information phase of its development, many challenges, threats, and risks arise. It is stipulated that the information environment becomes super national, planetary, boundless, which goes

(C) Н.М. Волвенко, 2020 
beyond the historically formed social control and social regulation of information relations. It is emphasized that social health, as a new notion of socio-political knowledge, is a complex and meaningful concept. It includes, above all, the social content of human health or the population as a whole. It was made an attempt to define the term "social health" in the context of the globalization of the information space: it is an achievement of such a social state, when the information interests and needs of society and individuals man not only do not contradict each other, are not implemented at the expense of others, but are harmonized in such a way that the main forms of informatization of all aspects of public life do not make the information environment hostile and aggressive for a person, do not contribute to the violation of its information rights and freedoms, do not make a person depressed or terrifying to action, do not contribute to its escape from reality, but is a means of developing its morality, culture, educational and professional development, as well as political activism.

It is highlighted the formats or levels of social health of society that provide real, complete, and comprehensive information security of a person: information-technological, information-civilizational, information-cultural, information-regulatory, information-legal, information-ontological, information-psychological, and information-propagandistic. The indicated levels of consideration are not abstractly separate levels of ensuring human information security in modern society. They form a coherent system.

It is concluded that beyond the identified parameters, in modern society, one can only speak about human information security, formulate ideological, legal, state doctrines of information security, etc. However, a truly information-protected person can only be in an information-healthy society.

Keywords: social health, the globalization of information space, social dialogue, human information security.

Постановка проблеми. Соціальне здоров’я суспільства є найважливішою умовою гармонізації інформаційних інтересів та інформаційних потреб держави, суспільства та людини i, в кінцевому рахунку, головною умовою інформаційної безпеки особистості. Щодо сучасної України, це виражається в становленні та розвитку в нашій державі інформаційної цивілізації. Розгляд проблеми соціального здоров’я суспільства, як найважливішої умови інформаційної безпеки людини, обумовлено тим, що зі вступом суспільства в інформаційну фазу свого розвитку виникає безліч викликів, загроз і ризиків, які не мають аналогів у попередній історії людської цивілізації. Це, перш за все, ризики глобалізації, бо інформаційне середовище, яке формується в інформаційному суспільстві, виступає як глобальний планетарний фактор розвитку. Відповідно до цього, всі основні ризики глобалізації в поєднанні з глобальним інформаційним простором формують нове середовище соціальних відносин. Це обумовлено тією обставиною, що процес інформатизації, заснований на лавиноподібному зростанні інформаційних технологій та їх проникненні в усі сфери 
суспільного життя, породжує цілий комплекс нових проблем, які відчутно позначаються на ще не створеній гармонізації інформаційних потреб суспільства й людини, що, безсумнівно, призводить до різних інформаційних загроз, в тому числі до погроз інформаційної безпеки як суспільства, так і людини. Так, «новітні електронні ЗМК, генеруючи інноваційні інформаційно-комунікативні обміни і контакти, що, у свою чергу, ... сприяє віртуалізації та медіатизації політичного простору, виникненню гиперреальності та трансформації механізмів боротьби і конкуренції за державну владу, у цілому стимулюють зміни алгоритму конструювання поля політики, у тому числі і його інституціональних компонентів» (Krasnokutska, 2008, s. 136). Багато в чому це пов’язано з тим, що інформаційне середовище стає наддержавним, планетарним, безмежним, що виходить за рамки сформованого історично соціального контролю і соціального регулювання інформаційних відносин.

У такому інформаційному переформатуванні соціальних відносин міститься безліч переваг інформаційного суспільства перед суспільством традиційним та індустріальним. Але в цьому також міститься безліч непередбачених соціальних наслідків, які таять в собі нові виклики й загрози. Так, всесвітня мережа розширює можливості вільного обміну думками, що сприяє розвиткові плюралістичного суспільства. Але, користуючись електронними медіа, не слід абсолютизувати їх позитивні риси, оскільки Інтернет може розмивати межі між актуальною і минулою інформацією, а також інтернет-журналістика позбавлена будь-яких табу, тому доволі важко перевірити якість та істинність цієї інформації (Yurchenko, 2008).

Аналіз актуальних досліджень. Різні аспекти даної проблематиці розглядаються в працях Т. Адорно, Е. Аронсон, Д. Белла, Ж.-П. Бодрійяра, К. Боулдинга, Н. Вінера, Р. Войтович, А. Етціоні, Ж.-Л. Сервана-Шрейбера, Т. Стоуньєра, Г. Тарда, А. Турена, Е. Тоффлера, К. Шеннона, У. Уівера та багатьох інших. 
Метою статті $\epsilon$ показати, що бурхливе зростання інноваційних інформаційних технологій призвело як до проривів в більшості областей, так і до появи нових викликів і загроз інформаційній безпеці, а також виділити основні рівні соціального здоров'я суспільства, які є необхідними умовами для забезпечення інформаційної безпеки суспільства. Справжня, повна та всебічна інформаційна безпека людини можлива, на наш погляд, лише тоді, коли суспільство розвивається за критеріями і в цілях соціального здоров’я.

Виклад основного матеріалу. Соціальне здоров'я, як нове поняття соціально-політичного знання, є складним комплексом і багатозначним концептом (Bezpalko red., 2008). Воно включає в себе, перш за все, соціальний зміст здоров’я людини або населення в цілому. «Офіційним документом, у якому було зафіксовано значимість здоров'я як соціального явища, був статут «Охорона народного здоров’я», прийнятий в Англії у XIX ст. Саме в ньому вперше згаданий термін «громадське здоров’я... Здоров’я населення - ... соціальна категорія, що відображає фізичне, психологічне, соціальне благополуччя людей, які здійснюють свою життєдіяльність у визначених соціальних спільнотах» (Bezpalko red., 2008, s. 7). Соціальне здоров’я суспільства в контексті глобалізації інформаційного простору розуміється нами як досягнення такого суспільного стану, коли інформаційні інтереси та інформаційні потреби суспільства й людини не тільки не суперечать один одному, не реалізуються одні за рахунок інших, а гармонізовані таким чином, що основні форми інформатизації всіх сторін суспільного життя не роблять інформаційне середовище ворожим й агресивним для людини, не сприяють порушенню іiі інформаційних прав i свобод, не роблять людину пригніченою або страхітливою до дії, не сприяють іï відходу від реальності, але є засобом розвитку іï моральності, культури, освітньо-професійного вдосконалення, а також політичної активності.

Виділимо наступні основні, на нашу думку, формати або рівні соціального здоров'я суспільства, які забезпечують справжню, повну i 
всебічну інформаційну безпеку людини: інформаційно-технологічний,

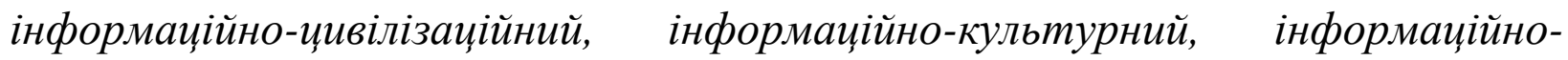
регулятивний, інформаційно-правовий, інформаційно-онтологічний, інформаційно-психологічний та інформаційно-пропагандистський. Зазначені рівні розгляду не $є$ абстрактно відокремленими рівнями забезпечення інформаційної безпеки людини в сучасному суспільстві, вони утворюють цілісну систему.

Розглянемо, насамперед, інформаційно-технологічний рівень соціального здоров’я суспільства. Бурхливе зростання інноваційних інформаційних технологій призвело як до проривів в більшості інших областей соціального, політичного, культурного та економічного життя, так і до появи нових викликів і загроз інформаційній безпеці. Світ, що констатує медіа, «не має чіткості або спрямованості. Світ пластичний - час у ньому можна легко повернути назад, а епізоди, що його заповнюють, перемістити в будь-якому порядку» (Kostenko, 1998, s. 141-142). В сучасному суспільстві стала немислимою будь-яка форма соціальної діяльності, яка ігнорує або не використовує досягнення цифрового світу. Соціальний світ змінився i перейшов в якісно новий стан. Він став інформаційним світом, в якому головною цінністю є інформація, способи їі виробництва, обміну, доставки та практичного використання. Сформувалося і безперервно розширюється нове середовище проживання людини нового типу - «Homo informaticus». Якщо раніше, на попередніх етапах соціальної еволюції людської цивілізації, середовищем, над яким надбудовувався соціум, була природна (екологічна) середа, то в зв’язку з інформаційною революцією таким стало інформаційне середовище. Це не природна, а рукотворна середа, що виникла під впливом інформаційно-комунікаційних технологій. Якщо відносини типу «природа i суспільство» раніше розглядалися як базові, то в інформаційну епоху актуальними стали відносини типу «інформаційне середовище i суспільство». 
Глобалізація інформаційного простору i віртуалізація комунікації призводять до появи нового типу людського мислення - Net-мислення, до нового типу людської свідомості - віртуальної трансперсональної свідомості, до нового типу психіки - психіки людини типу «Ноmo informaticus». Це призводить до того, що «в умовах автоматизованого суспільства масова комунікація виконує функцію компенсації та заміщення зруйнованих соціальних зв'язків і в силу цього чинить на кожного окремо ізольованого індивіда нічим не опосередкований вплив, якому він зовсім не в змозі протистояти» (Dyakova i Trahtenberg, 1999, s. 32). Віртуальна свідомість трансперсональна, і саме в цьому реалізується іiі анонімність. Н. Байм (2002) називає трансперсональність індивідуальної віртуальної свідомості надіндивідуальністю. Net-мислення має символічний характер, зумовлений тим, що в процесі комунікації відбувається обмін символами і образами, але не сенсами. Формована під впливом Net-мислення мозаїчна картина світу стає домінуючою тенденцією в освіті та культурі, для якої характерні символічний хаос сприйнять, сум'яття і плутанина сенсів, однобокі знання, збиткова освіченість, міфологеми переконань, ілюзї̈ уявлень, неупереджені помилки, навмисна дезінформація і маніпуляція (Вауm, 2002). Найбільш повно мозаїчна картина світу виявляється в, так званому, кліповому мисленні. Кліпове мислення, як ми розуміємо, - це мислення споживача, користувача дозованої інформації, яка мозаїчно препарована, молекулярно виділена і в доступній простій формі подана.

Дисгармонійна побудова інформаційних потоків, деструктивна i руйнівна інформація, яка впливає на людину негативним чином, пригнічує тї, породжує інформаційні стреси, страхи та фобії. Це також несанкціоноване впровадження різних рекламних роликів та іншого інформаційного «сміття» в різні інформаційні повідомлення, які потрібні користувачеві. Все це створює умови для суттєвих загроз інформаційній безпеці людини.

Отже, інформаційно-технологічний рівень соціального здоров'я забезпечується тим, що в суспільстві не розробляються i не 
використовуються інформаційні технології, які можуть завдати матеріальної, економічної, психологічної або моральної шкоди людині, користувачеві інформаційними технологіями. Інформаційно-технологічний рівень соціального здоров’я також характеризується тим, що формуюче в суспільстві інформаційне середовище не $\epsilon$ ворожим й агресивним по відношенню до людини, воно не перевантажене i не забруднене недостовірними інформаційними повідомленнями.

Інформаційно-цивілізащійний рівень соціального здоров’я суспільства, на наш погляд, характеризується тим, що інформаційно-комунікаційні відносини, що розвиваються в суспільстві, повинні сприяти солідаризації суспільства, протистояти його роз’єднанню, атомізації, сприяти розвитку соціального діалогу між соціальними інститутами, різноманітними громадськими об’єднаннями та людьми. Можливість гармонії між різними, в тому числі й інформаційними інтересами і потребами суспільства, його соціальних інститутів, громадських об'єднань та людей, на нашу думку, може бути забезпечена за допомогою соціального діалогу. Саме соціальний діалог, як форма розвинених соціальних зв'язків і взаємин, містить в собі потенціал соціального згуртування, солідаризації та соціалізації, оскільки за своєю суттю означає вільну взаємодію рівноправних партнерів (Kurbatov, 2014). Як підкреслює А. Реквіц (2002), бути суб’єктом соціального діалогу, тобто бути творцем комунікативного соціуму, - означає свідомо, цілеспрямовано і у відповідності зі сформованими соціокультурними правилами і нормами, брати участь в даному процесі.

Суспільство, яке досягло цивілізаційного розвитку, що проявляється в соціальному діалозі, характеризує такі особливості соціуму, як соціальна солідарність, толерантність і зрілість соціально-політичних відносин, що повинні сприяти громадянському миру, соціальній злагоді, партнерству, відкритості та гласності. Можна сказати, що ступінь цивілізованості суспільства залежить від розвитку рефлексивності особистостей, здатних реалізувати соціальний діалог. Соціальний діалог $\epsilon$ неодмінною умовою 
гармонії інформаційних інтересів та інформаційних потреб суспільства в прояві всіх його соціальних інститутів і кожної людини, що є гарантією інформаційної безпеки як суспільства, так і людини. Суспільні відносини, засновані на соціальному діалозі, $є$ перешкодою відчуження людини i атомізації громадських відносин, чому значною мірою сприяє глобалізація інформатизації та інформаційних відносин. Якщо людина цілком занурює свою людську сутність в інформаційний світ, у його бази даних, в сервери, в сукупність інформаційних вузлів, інформаційні мережі та інші прояви цифрового світу, це означає, в певному сенсі, що відбулося відчуження людської сутності від самої людини і суспільства 3 його сукупністю соціальних відносин в традиційному їх розумінні, відчуження в користь світу цифрового, світу інформаційного. Індикатором відчуження сутності людини стає інформаційне середовище, яке проникло в усі сфери людських відносин і зробило ці людські відносини цифровими, інформаційними, віртуальними. I це, на наш погляд, головна підстава всіх загроз і ризиків інформаційної безпеки людини в інформаційному світі. «Зміни, які лежать в основі нової соціальної організації, створили ситуацію, у якій динаміка ідентичності значно прискорилась, а це, у свою чергу, призвело до переосмислення ідентифікації та самоідентифікації, до прискорення темпів перетворення ідентичності, появи нових глобальних рис ідентичності, посилення уваги до антиглобалістських тенденцій як протилежних форм глобальної ідентичності» (Voitovych, 2010, s. 11). Отже, грані ризиків та загроз - цекриза ідентичності, моральні та етичні деформації сучасного суспільства, підміна реальності, трансформації соціально-політичних процесів в сторону гібридних дублікатів, криза загальнолюдських цінностей, підміна їх псевдоцінностями, ілюзіями, соціальними химерами та ін.

Сучасні тенденції до індивідуалізації і атомізації соціальних зв’язків в суспільстві, що характеризуються 3. Бауманом (2005) як індивідуалізоване суспільство, а Ж. Бодрійяром (2006) - як суспільство споживання, в реальному людському вимірі чреваті особистою і соціальною самотністю. 
Мережева свобода дає ілюзію причетності, колективної дії, але це лише виражається в тому, що традиційно називається самотністю в мережі. Подолання цих укорінених в інформаційному суспільстві тенденцій соціального і особистісного відчуження, атомізації, індивідуалізації та домінування споживчих цінностей, як досягнення високого цивілізаційного рівня розвитку $\epsilon$, на нашу думку, найважливішою передумовою самодостатності суспільства і людини, їх незалежності та інформаційної безпеки. У такій же мірі це стосується і вибудовування цивілізаційних бар'єрів на шляху таких деструктивних форм соціальної інформаційної взаємодії, як інформаційні війни, інформаційне протиборство, інформаційний тероризм і інформаційна злочинність.

Отже, інформаційно-цивілізаційний рівень соціального здоров'я суспільства характеризується тим, що інформаційно-комунікаційні відносини сприяють солідаризації та розвитку соціального діалогу між соціальними інститутами та людьми.

Під наступним, інформаиійно-культурним рівнем, ми розуміємо, перш за все, такий розвиток інформаційних форм соціальної взаємодії, який здійснюється відповідно 3 соціокультурними нормами і цінностями, i виражається у високому рівні розвитку інформаційної культури суспільства та людини. Інформаційна культура являе собою досить багатозначне поняття. Це такий рівень організації інформаційних процесів та взаємодії в суспільстві, ефективності створення, збору, зберігання, переробки і передачі інформації, який відповідає соціокультурним нормам і цінностям, котрі склалися в суспільстві (Kirilenko, 2008). Звісно, держава виступає як цілісність людського буття, яка організована відповідно до певної ціннісної ієрархії. Але держава і мережеве суспільство - це різні соціокультурні утворення: «держава - це розгорнута по вертикалі владна структура, яка володіє повноцінною (у тому числі й духовною) онтологією, територією, історією... Що ж стосується мереж, то вони за визначенням володіють функціональною природою, будучи зоріснтованими на ті чи інші фрагменти 
соціальної дійсності»») (Voitovych, 2010, s. 16). Слід зазначити, що саме нова інформаційно-комунікативна культура зумовлює конструювання нової моделі суспільного розвитку. Ця нова модель базується на констатації нових символів, формуванні нового мережевого світогляду, що викликано глобалізацією інформаційного простору.

Глобалізація планетарного і безмежного інформаційного середовища в умовах існування сформованого соціально-державного устрою сама по собі представляє цивілізаційний виклик, до якого ще не цілком готові як суспільство, так і людина. Перш за все, це стосується неконтрольованого розповсюдження різної інформації. Розвинуте інформаційне суспільство передбачає наявність соціального контролю за поширенням інформації. Отже, інформаційно-регулятивний рівень характеризується тим, що розвиток i використання інформаційних технологій перебуває під громадським контролем, здійснюваним виходячи 3 гармонії інформаційних інтересів та потреб суспільства і людини 3 метою недопущення антисоціальної, антигуманної, недостовірної та провокаційної інформації, яка може нанести шкоду і суспільству, і людині. А це, на наш погляд, визначається рівнем сформованості демократичних інститутів громадянського суспільства.

Інформаційно-правовий рівень соціального здоров'я суспільства включає в себе наступні два аспекти. Це вироблення норм інформаційного права і реальне забезпечення інформаційного права людини. На наш погляд, основним предметом правового регулювання інформаційного права повинні бути інформаційні відносини, що складаються в суспільстві. Відрегульовані нормами інформаційного права, інформаційні технології повинні сприяти гармонійному розвитку інформаційного суспільства й бути підставою гармонізації інформаційних потреб та інтересів суспільства і людини, що, як нами вже зазначалося вище, є необхідною умовою інформаційної безпеки суспільства та людини. Норми інформаційного права, в якості базового пріоритету інформаційного суспільства, повинні розглядати, насамперед, забезпечення прав людини та їі основних свобод в інформаційній сфері, тому 
інформаційне право має орієнтуватися на статті та положення Загальної декларації прав людини, прийнятою резолюцією Генеральної Асамблеї ООН від 10 грудня 1948 року, і наступні документи ЮНЕСКО (Organizatsiya Ob'edinyonnyih Natsiy, 2019). Отже, інформаційно-правовий рівень характеризується тим, що інформаційні взаємовідносини регулюються нормами права, які формулюються виходячи 3 гармонії інформаційних інтересів та потреб суспільства та людини.

Явища електронно-цифрового світу століття інформатизації породжують нову форму культурного буття людини (інформаційнокультурне буття), але одночасно породжують нові загрози і небезпеки для людини. Як вважає Й. Хейзинга (2004, s. 403), «наука не стримувана більше вуздою вищого морального принципу, без опору віддає свої секрети техніці, що гігантські розвивається, що штовхається меркантилізмом, а техніка ще менш утримувана вищим принципом, на якому тримається культура... Техніка поставляє все, чого потребує суспільство для розвитку відносин i задоволення потреб.., однак суспільство при його нинішній структурі ще не в змозі реалізувати все те, що могла б дати йому техніка в галузі житла, їжі, засобів пересування й поширення ідей». Відбувається підміна однієї реальності іншою за допомогою заміщення традиційної реальності інформаційною віртуальністю. Таким чином, інформаџійно-онтологічний рівень транслює нам, що в інформаційному середовищі суб’єкт новітніх технологій замикається виключно в рамках користувача, для якого віртуальна реальність підміняє й заміняє справжню соціальну реальність. В інформаційно здоровому суспільстві межі між реальним соціальним буттям і буттям електронно-цифровим не розмиваються i культурний потенціал суспільства всіляко підтримує таке розмежування.

Соціальність, як конкретно-історична якість, сьогодні без вказівки на те, що вона «інформаційна» та «комунікаційна», а також без характеристик «глобальна» i «віртуальна» вже i не розглядається. Це ставить за мету виявлення такого рівня соціального здоров’я суспільства, як інформаційно- 
психологічний рівень. Інформаційно-психологічний рівень, на нашу думку, характеризується тим, що атмосфера інформаційного світу формується під позитивним соціально-психологічним впливом на суб'єктів новітніх технологій, не викликає інформаційного пригнічення їхньої психіки (стресів, фобій, залежностей) та не містить в собі деструктивної психологічної агресії.

Близьким за своєю значимістю до інформаційно-психологічного рівня $€$ рівень інформащійно-пропагандистський, який хоча і відрізняється за предметним наповненням, але близький до психологічного рівня методами впливу на свідомість всього суспільства і окремих людей. Українська дослідниця Р. Войтович (2010, s. 9-10) зауважує, що в сучасних умовах «глобальні медіаструктури перебувають у тісному зв'язку з політичними структурами, бо саме завдяки їм формується політична думка, визначаються стандарти політичної поведінки, структуруються мережі політичної боротьби... Слід зазначити, що глобальні медіаструктури стали нині ефективним механізмом формування позитивного і негативного іміджу як державної влади, так i держави в цілому». Отже, інформаційнопропагандистський рівень соціального здоров'я суспільства характеризується тим, що вплив ЗМІ та засобів пропагандистського забезпечення $\epsilon$ інформаційним, а не маніпулятивним. В інформаційно здоровому суспільстві люди не є об'єктом інформаційної агресії, засобом отримання інформаційних вигод і переваг, в тому числі й інформаційного прибутку, - вони не є об'єктом маніпуляції. В іншому випадку інформаційну безпеку людини неможливо гарантувати.

Висновки і перспективи подальших досліджень. Таким чином, аналіз показує, що виявлені параметри соціального здоров'я суспільства є абсолютно необхідними умовами забезпечення інформаційної безпеки людини. Поза цими умовами і за їх межами про інформаційну безпеку людини в сучасному суспільстві можна тільки говорити, формулювати ідеологічні, правові, державні доктрини інформаційної безпеки, ставити цілі і 
завдання, намічати терміни реалізації та ін. Але реально інформаційно захищеною людина може бути тільки в інформаційно здоровому суспільстві.

\section{ЛІТЕРАТУРА}

1. Бауман, 3. 2005. Индивидуализированное обшество. Москва: Логос.

2. Безпалько, О. В. ред., 2008. Основи громадського здоров'я: теорія і практика. Ужгород: ВАТ «Патент».

3. Бодрийяр, Ж. 2006. Общество потребления. Его мифы и структуры. Москва: Республика; Культурная революция.

4. Войтович, Р., 2010. Мережеве суспільство як нова форма соціальної організації в умовах глобалізації. Політичний менеджмент, 6(45), с. 7-20.

5. Дьякова, Е. и Трахтенберг, А. 1999. Массовая коммуникация $u$ проблема конструирования реальности: анализ основных теоретических подходов. Екатеринбург: УрО РАН.

6. Кириленко, А. 2008. Основы информационной культуры. СПб: СПбГУ ИТМО.

7. Костенко, Н., 1998. Парадигми та фактичності нових мас-медіа. Соціологія: теорія, методи, маркетинг, 1-2, с. 138-150.

8. Краснокутська, Ю. С., 2008. Особливості інституціональних змін поля політики в умовах розвитку сучасного інформаційного суспільства: роль мас-медіа. Вісник Харківського начіонального університету імені В. Н. Каразіна, 796, с. 132-136.

9. Курбатов, В.И., 2014. Социальный диалог: концептуальный анализ. Гуманитарий Юга России, 1, с. 103-112.

10. Организация Объединённых Наций, 2019. Всеобщая декларащия прав человека. [online] Доступн: https://www.un.org/ru/universal-declarationhuman-rights/index.html [Дата звернення 12 Листопад 2019].

11. Хейзинга, Й. 2004. Homoludens. В тени завтрашнего дня. Moskva: ACT.

12. Юрченко, Є., 2008. Особливості використання Інтернету у виборчій кампанії. Віче, 2, с. 22-24.

13. Baym, N., 2002. Interpersonal Life Online. In: L. A. Lievrouw \& S. Livingstone. Handbook of New Media: Social Shaping and Consequences of ICTs. Livingstone: Sage Publications.

14. Reckwitz, A., 2002. Toward a Theory of

\section{REFERENCES}

1. Bauman, Z. 2005. Individualizirovannoe obschestvo. Moskva: Logos.

2. Bezpalko, O. V. red., 2008. Osnovy hromadskoho zdorovia: teoriia i praktyka. Uzhhorod: VAT «Patent».

3. Bodriyyar, Zh. 2006. Obschestvo potrebleniya. Ego mifyi i strukturyi. Moskva: Respublika; Kulturnaya revolyutsiya.

4. Voitovych, R., 2010. Merezheve suspilstvo yak nova forma sotsialnoi orhanizatsii $\mathrm{v}$ umovakh hlobalizatsii. Politychnyi menedzhment, 6(45), s. 7-20.

5. Dyakova, E. i Trahtenberg, A. 1999. Massovaya kommunikatsiya i problema konstruirovaniya realnosti: analiz osnovnyih teoreticheskih podhodov. Ekaterinburg: UrO RAN.

6. Kirilenko, A. 2008. Osnovyi informatsionnoy kulturyi. SPb: SPbGU ITMO.

7. Kostenko, N., 1998. Paradyhmy ta faktychnosti novykh mas-media. Sotsiolohiia: teoriia, metody, marketynh, 1-2, s. 138-150.

8. Krasnokutska, Yu. S., 2008. Osoblyvosti instytutsionalnykh zmin polia polityky $\mathrm{v}$ umovakh rozvytku suchasnoho informatsiinoho suspilstva: rol mas-media. Visnyk Kharkivskoho natsionalnoho universytetu imeni V. N. Karazina, 796, s. 132-136.

9. Kurbatov, V.I., 2014. Sotsialnyiy dialog: kontseptualnyiy analiz. Gumanitariy Yuga Rossii, 1, s. 103-112.

10. Organizatsiya Ob'edinyonnyih Natsiy, 2019. Vseobschaya deklaratsiya prav cheloveka. [online] Dostupno: https://www.un.org/ru/universal-declarationhuman-rights/index.html [Data zvernennya 12 Lustopad 2020].

11. Heyzinga, Y. 2004. Homoludens. $V$ teni zavtrashnego dnya. Moskva: AST.

12. Yurchenko, Ye., 2008. Osoblyvosti vykorystannia Internetu u vyborchii kampanii. Viche, 2, s. 22-24.

13. Baym, N., 2002. Interpersonal Life Online. In: L. A. Lievrouw \& S. Livingstone. Handbook of New Media: Social Shaping and Consequences of ICTs. Livingstone: Sage Publications.

14. Reckwitz, A., 2002. Toward a Theory of Social Practices. A Development in Cultural 
Social Practices. A Development in Cultural Theorizing. European Journal of Social Theory, 5(2), p. 243-263.
Theorizing. European Journal of Social Theory, 5(2), p. 243-263.

\section{Інформація про автора}

Волвенко Наталія Миколаївна - доцент кафедри вітчизняної та зарубіжної історії Горлівського інституту іноземних мов ДВНЗ «Донбаський державний педагогічний університет» (м. Бахмут), e-mail: volvenko2018@gmail.com; ORCID: https://orcid.org/00000003-3443-2082

Стаття надійшла до редакції: 27.11.2019 p. $\quad$ Прийнята до друку: 13.12.2019 p. 